\title{
Clinical correlates of B-type natriuretic peptide monitoring in outpatients with left ventricular assist device
}

\author{
Marketa Hegarova ${ }^{a}$, Milos Kubanek ${ }^{a}$, Ivan Netukab , Jiri Malyb , Zora Dorazilovaa , Tomas Gazdic ${ }^{\mathrm{b}}$, Janka Franekovac, \\ Vera Lanska ${ }^{d}$, Vojtech Melenovsky ${ }^{a}$, Josef Kautzner ${ }^{\mathrm{a}}$, Ivan Malek ${ }^{\mathrm{a}}$
}

Background. B-type natriuretic peptide (BNP) is a strong predictor of prognosis in chronic heart failure. We aimed to evaluate the clinical correlates and interpretation of BNP monitoring in LVAD out-patient recipients.

Methods. We performed a prospective study in 136 individuals after HeartMate II LVAD implantation. During follow-up they were divided into group A (severe adverse events requiring hospitalisation), group B (mild to moderate adverse events) and group C (an uneventful course). BNP was measured pre-implant, at the first out-patient visit, and then every 2 months. We identified the lowest level, and the level at the clinical event and/or the highest value in patients without clinical events (BNP peak).

Results. During a median follow-up of 298 days, 8 patients (6\%) died, 21 patients (15\%) experienced a severe adverse event (group A) and 38 patients (28\%) had other adverse event (group B). Both the absolute value of BNP peak and its percentage values relative to pre-implant, first visit and minimum BNP had similar areas under the curve (AUC) to identify individuals with adverse events (group A and B) from group C. The performance of BNP peak rose from detection of infection to diagnosis of heart failure and culminated in individuals with pump thrombosis (AUC 0.68 vs. 0.75 vs. 0.93 ). Conclusions. Serial measurement of BNP in outpatients with LVAD correlates with the occurrence of adverse events. Assessment of absolute values of BNP peak seems to have a similar accuracy to analysis of intra-individual variation of BNP and it is more practical.

Key words: prognosis, B-type natriuretic peptide, ventricular assist devices, advanced heart failure

Received: January 25, 2017; Accepted: February 17, 2017; Available online: February 27, 2017

https://doi.org/10.5507/bp.2017.003

${ }^{a}$ Department of Cardiology, Institute for Clinical and Experimental Medicine, Prague, Czech Republic

${ }^{b}$ Department of Cardiac Surgery, Institute for Clinical and Experimental Medicine, Prague, Czech Republic

'Department of Laboratory Methods, Institute for Clinical and Experimental Medicine, Prague, Czech Republic

${ }^{d}$ Department of Biostatistics, Institute for Clinical and Experimental Medicine, Prague, Czech Republic

Corresponding author: Milos Kubanek, e-mail: milos.kubanek@ikem.cz

\section{INTRODUCTION}

Implantation of a durable left ventricular assist device (LVAD) is an accepted life-saving procedure in the terminal phase of chronic heart failure (CHF) (ref. $\left.{ }^{1}\right)$. Survival after LVAD placement can be reduced by complications such as thromboembolism, haemorrhage, right ventricular failure, development of aortic regurgitation, pump thrombosis and drive line or pump infection ${ }^{2}$. Early detection and effective management of these adverse events are mandatory to ensure long-term survival of LVAD recipients. Monitoring of B-type natriuretic peptide (BNP) plasma levels could detect some of these complications. Elevated BNP plasma levels reflect either increased release from cardiac myocytes due to increased wall stress or decreased renal clearance in renal impairment ${ }^{3}$. This happens not only in heart failure but also in other settings like sepsis and cardiac inflammatory disease ${ }^{4}$. All of these pathophysiological mechanisms might be relevant to LVAD patients.

There is extensive evidence for the diagnostic ${ }^{5,6}$ and prognostic ${ }^{7-10}$ use of BNP and/or N-terminal pro BNP in individuals with acute and chronic heart failure. Surprisingly, there are scarce data regarding BNP moni- toring after LVAD placement. Decreased left-ventricular (LV) filling pressures, reduction of LV size and LV mass, and improved renal function after LVAD implantation should lead to decrease in BNP plasma levels ${ }^{11,12}$. Indeed, $\mathrm{LV}$ reverse remodeling after LVAD implantation was associated with decrease in BNP plasma levels ${ }^{13-15}$. Decreased BNP synthesis has been documented even in myocardial samples ${ }^{16,17}$. However, there are few studies assessing the relationship between serial monitoring of BNP plasma levels and clinical events after LVAD placement ${ }^{18}$. We hypothesized that recent plasma level during BNP monitoring will correlate with clinical events and complications in outpatient settings. In addition, we assessed whether analysis of intra-individual variation of BNP plasma levels will be more effective than evaluation of the most recent absolute values of BNP.

\section{METHODS}

\section{Study population}

We performed a prospective cohort study in consecutive patients who underwent implantation of LVAD HeartMateII 
(Thoratec Corporation, Pleasanton, CA, USA) in our institution between February 2008 and November 2015. The LVAD was implanted as a bridge to transplantation and we included patients who entered out-patient follow-up in Heart Failure Clinic of our institution (Institute for Clinical and Experimental Medicine, Prague, Czech Republic). Of 187 HeartMateII recipients, we excluded 29 patients (15\%) who died during the initial hospitalization, 1 patient who died of stroke shortly after discharge, 8 patients who underwent heart transplantation during the initial hospitalization, 10 patients with missing pre-implant BNP plasma level, 2 patients with pre-implant renal replacement therapy and 1 patient with ongoing hospitalization. A total of 136 individuals (73\%) were enrolled in the study.

\section{Study protocol}

BNP plasma levels were assessed pre-implant in the morning before LVAD placement and then post-implant every 2 months during clinical check ups which were scheduled every 4 weeks. In addition, we collected data regarding clinical status, mean arterial blood pressure measured by Doppler method on the brachial artery, blood count, routine biochemistry, C-reactive protein (CRP) and electrocardiography. At each clinical check up, we assessed clinical status and complications using the following scale: $0=$ no clinical event, $1=$ hypervolemia requiring increase in oral diuretics, $2=$ arterial hypertension with mean $\mathrm{BP} \geq 110 \mathrm{mmHg}, 3=$ infection without need of hospitalization, parenteral antibiotics or major surgery, 4 = severe infection requiring hospitalization, parenteral antibiotics or major surgery, $5=$ heart failure without pump dysfunction with hospitalization and parenteral treatment, $6=$ pump dysfunction with abnormal echocardiographic or angiography findings. The patients were divided according to the above complications into the following three groups: group A with severe events requiring hospitalization (4-6), group B with less severe events managed in the out-patient settings (1-3) and group $\mathrm{C}$ without any of the above complications. The follow-up was closed on the $1^{\text {st }}$ of June 2016.

\section{Laboratory methods}

Blood samples for the measurement of plasmatic levels of BNP were collected into tubes containing ethylenediaminetetraacetic acid (EDTA) $(1 \mathrm{mg} / \mathrm{mL})$ and aprotinin (500 kallikrein inactivator $\mathrm{U} / \mathrm{mL}$ ). Test tubes were immediately centrifuged. Plasma levels of BNP were measured using a chemiluminescent immunoaassay (Abbott Laboratories, Diagnostics Division, Abbott Park, USA Illinois, Supplier: Abbott, Max-Planck-Ring 2, Wiesbaden, Germany). The lower limit of detection was $10 \mathrm{ng} / \mathrm{L}$, intra-assay coefficient of variation $(\mathrm{CV})<3.8 \%$, and inter-assay $\mathrm{CV}<5.3 \%$. For serum creatinine assessment, we used an enzymatic method (Abbott Architect Creatinine, catalogue No. 8L2431, Abbott Laboratories Inc., Abbott Park, IL, USA).

\section{Analysis of laboratory data}

All patients had available pre-implant BNP plasma level (BNP pre-implant) and at the first outpatient visit (BNP first visit). In 125 patients with fluctuating BNP plasma levels, we identified the BNP plasma level at the predefined clinical event (BNP peak), or the highest value in individuals with event-free follow-up (BNP peak), which had to be higher than the plasma level at the first visit. In a patient with several clinical events we chose the BNP value at the clinically most severe event according to the scale. In addition, the lowest post-implant value of BNP previous to BNP peak was recorded (BNP minimum). To assess intra-individual variation of BNP levels, we calculated what percentage of the BNP pre-implant, $\mathrm{BNP}$ at the first out-patient visit and BNP minimum the BNP peak represented. This analysis was not possible in a small subgroup of 11 patients ( $8 \%$ ) who had sustained decrease in BNP plasma levels after implantation and their highest BNP level was the first. Their outcomes are shown separately.

To assess the role of renal function in the BNP variation, glomerular filtration rate (GFR) was estimated using the Cockroft-Gault formula ${ }^{19}$. We applied the following equation in males: GFR $(\mathrm{mL} / \mathrm{s})=140$-age [years]) $\mathrm{x}$ weight $[\mathrm{kg}] / 44,5 \mathrm{x}$ plasma creatinine $[\mu \mathrm{mol} / \mathrm{L}]$ and another equation in females: GFR $(\mathrm{mL} / \mathrm{s})=0,85 \times(140$ -age [years]) x weight [kg] / 44,5 x plasma creatinine $[\mu \mathrm{mol} / \mathrm{L}]$. In three patients with known muscular dystrophy, we estimated GFR from the cystatin clearance: $\operatorname{GFR}(\mathrm{mL} / \mathrm{s})=84,7 \times$ plasma cystatin $\mathrm{C}[\mathrm{mg} / \mathrm{L}]^{-1,68} / 60$.

\section{Statistical analysis}

Categorical data were described using absolute and relative frequencies, and compared using chi-squared analysis or Fisher exact test. Continuous variables were assessed for normality by the Kolmogorov-Smirnov test. Normal variables were expressed as a mean and standard deviation. Variables with abnormal distribution were shown as a median and interquartile range. They were log-transformed for analytical purposes (i.e. BNP). Comparison of continuous variables was performed using the Student t test for unpaired data or by the non-parametric Mann-Whitney test where appropriate. Differences between groups were tested by ANOVA. ROC analysis was used to identify predictors of clinical events and optimal cutpoints using the highest Youden index. Kaplan-Meier curves were constructed to demonstrate the relationship between selected variables and time to events. All tests were two-sided and $P$-values less than 0.05 were considered statistically significant. JMP12 (SAS, Buckinghamshire, UK) and SPSS (Chicago, Illinois, USA) for Windows, version 17.0 .

\section{Ethics}

The investigation conforms to the principles outlined in the Declaration of Helsinki. It was approved by the local ethics committee. All subjects gave their written informed consent prior to their participation in the study.

\section{RESULTS}

The study group included 136 LVAD recipients. Their characteristics are shown in Table 1. During a median 
Table 1. Study group characteristics and comparison of groups with adverse events and an uneventful clinical course.

\begin{tabular}{|c|c|c|c|c|c|c|}
\hline & \multirow[t]{2}{*}{$\begin{array}{l}\text { Group A } \\
(\mathrm{n}=21 \mathrm{pts})\end{array}$} & \multirow[t]{2}{*}{$\begin{array}{l}\text { Group B } \\
(\mathrm{n}=38 \mathrm{pts})\end{array}$} & \multirow[t]{2}{*}{$\begin{array}{l}\text { Group C } \\
(\mathrm{n}=66 \mathrm{pts})\end{array}$} & \multirow[t]{2}{*}{$\begin{array}{l}\text { Group D } \\
(\mathrm{n}=11)\end{array}$} & \multicolumn{2}{|c|}{$\begin{array}{c}\text { Statistical } \\
\text { significance }(P)\end{array}$} \\
\hline & & & & & $\begin{array}{c}\mathrm{A}+\mathrm{B} \\
\text { vs. } \mathrm{C}(+\mathrm{D})\end{array}$ & A vs. B \\
\hline Males/Females & $18(85 \%) / 3(15 \%)$ & $33(86 \%) / 5(14 \%)$ & $59(89 \%) / 7(11 \%)$ & $11(100 \%) / 0$ & 0.643 & 1.000 \\
\hline Mean age (days) & $\begin{array}{c}49.6 \\
(23-72)\end{array}$ & $\begin{array}{c}52.6 \\
(26-67)\end{array}$ & $\begin{array}{c}47.2 \\
(17-69)\end{array}$ & $\begin{array}{c}53.5 \\
(36-67)\end{array}$ & 0.141 & 0.584 \\
\hline $\begin{array}{l}\text { Aetiology: } \\
\text { Cardiomyopathy } \\
\text { Ischemic } \\
\text { Valve disease } \\
\text { Congenital }\end{array}$ & $\begin{array}{c}10(47.6 \%) \\
7(33.3 \%) \\
2(9.5 \%) \\
2(9.5 \%)\end{array}$ & $\begin{array}{c}21(55.3 \%) \\
16(42.1 \%) \\
1(2.6 \%) \\
0\end{array}$ & $\begin{array}{c}36(54.5 \%) \\
27(40.9 \%) \\
1(1.5 \%) \\
2(1.5 \%)\end{array}$ & $\begin{array}{c}6(54.5 \%) \\
4(36.4 \%) \\
0 \\
1(9.1 \%)\end{array}$ & 0.467 & 0.151 \\
\hline $\begin{array}{l}\text { Duration of follow-up } \\
\text { (days) }\end{array}$ & $267(157-422)$ & $356(263-532)$ & $298(157-414)$ & $96(33-169)$ & $0.029 *$ & 0.096 \\
\hline Body mass index $\left(\mathrm{kg} / \mathrm{m}^{2}\right)$ & $27.5 \pm 4.2$ & $26.8 \pm 4.3$ & $26.0 \pm 3.9$ & $24.0 \pm 3.5$ & 0.084 & 0.393 \\
\hline $\begin{array}{l}\text { INTERMACS } \\
1 \\
2 \\
3 \\
4 \\
5 \\
\end{array}$ & $\begin{array}{c}4(19 \%) \\
6(29 \%) \\
8(38 \%) \\
1(5 \%) \\
2(9 \%)\end{array}$ & $\begin{array}{c}6(16 \%) \\
10(26 \%) \\
10(26 \%) \\
7(19 \%) \\
5(13 \%)\end{array}$ & $\begin{array}{c}11(17 \%) \\
28(42 \%) \\
16(24 \%) \\
8(12 \%) \\
3(5 \%)\end{array}$ & $\begin{array}{c}2(18 \%) \\
6(54 \%) \\
1(9 \%) \\
2(18 \%) \\
0 \\
\end{array}$ & 0.556 & 0.603 \\
\hline $\begin{array}{l}\text { Short term MCS } \\
\text { before implant }\end{array}$ & $5(24 \%)$ & $9(24 \%)$ & $14(21 \%)$ & 0 & 0.358 & 1.000 \\
\hline Combined surgery: & & & & & & \\
\hline Aortic valve & $4(19 \%)$ & $2(5 \%)$ & $6(9 \%)$ & 0 & 0.304 & 0.173 \\
\hline Mitral valve & 0 & $1(3 \%)$ & $6(9 \%)$ & 0 & 0.228 & 1.000 \\
\hline Tricuspid valve & $6(29 \%)$ & $9(24 \%)$ & $18(27 \%)$ & $2(18 \%)$ & 0.901 & 0.759 \\
\hline RVAD & $2(9 \%)$ & $6(16 \%)$ & $2(3 \%)$ & 0 & 0.079 & 0.699 \\
\hline Days in ICU (day) & $17(7.5-27.0)$ & $9(6.0-21.5)$ & $7(5.0-20.0)$ & $7(4-13)$ & 0.013 * & 0.161 \\
\hline BNP pre-implant (ng/L) & $\begin{array}{c}1118.7 \\
(771.0-2532.5)\end{array}$ & $\begin{array}{c}1762.1 \\
(1284.8-2155,5)\end{array}$ & $\begin{array}{c}2253.0 \\
(1501.8-3466.0)\end{array}$ & $\begin{array}{c}2558.0 \\
(824-3083)\end{array}$ & $0.001 * *$ & 0.056 \\
\hline BNP first visit (ng/L) & $\begin{array}{c}411.0 \\
(227.5-651.0) \\
\end{array}$ & $\begin{array}{c}446.5 \\
(278.3-809.5) \\
\end{array}$ & $\begin{array}{c}292.5 \\
(189.0-498.8)\end{array}$ & $\begin{array}{c}377.0 \\
(201.0-472.0) \\
\end{array}$ & $0.001 * *$ & 0.542 \\
\hline BNP minimum (ng/L) & $\begin{array}{c}206.5 \\
(132.5-374.0) \\
\end{array}$ & $\begin{array}{c}217.0 \\
(163.5-300.8) \\
\end{array}$ & $\begin{array}{c}169.5 \\
(111.3-275.5)\end{array}$ & - & 0.067 & 0.987 \\
\hline BNP peak (ng/L) & $\begin{array}{c}1220.7 \\
(785.0-1434.5)\end{array}$ & $\begin{array}{c}506.0 \\
(416.0-823.8)\end{array}$ & $\begin{array}{c}246.5 \\
(163.0-452.3)\end{array}$ & - & $0.000 * * *$ & $0.000 * * *$ \\
\hline $\begin{array}{l}\text { BNP peak to BNP pre- } \\
\text { implant percentage }(\%)\end{array}$ & $88(44-113)$ & $31(23-54)$ & $14(5-23)$ & - & $0.000 * * *$ & $0.000 * * *$ \\
\hline $\begin{array}{l}\text { BNP peak to BNP first } \\
\text { visit percentage }(\%)\end{array}$ & $223(201-414)$ & $101(100-149)$ & $100(68-114)$ & - & $0.000 * * *$ & $0.000 * * *$ \\
\hline $\begin{array}{l}\text { BNP peak to BNP } \\
\text { minimum percentage }(\%)\end{array}$ & 449 (314-904) & $263(191-335)$ & $140(125-172)$ & - & $0.000 * * *$ & $0.000 * * *$ \\
\hline $\begin{array}{l}\text { GFR pre-implant } \\
(\mathrm{ml} / \mathrm{s})\end{array}$ & $1.71(1.37-2.07)$ & $1.55(1.19-1.54)$ & $1.47(1.13-1.82)$ & $1.65(1.21-1.58)$ & 0.218 & 0.289 \\
\hline $\begin{array}{l}\text { GFR at minimum BNP } \\
(\mathrm{mL} / \mathrm{s})\end{array}$ & $1.95(1.35-2.40)$ & $1.77(1.35-2.21)$ & $1.87(1.43-2.37)$ & $1.73(1.38-2.24)$ & 0.961 & 0.752 \\
\hline $\begin{array}{l}\text { GFR at peak BNP } \\
(\mathrm{mL} / \mathrm{s})\end{array}$ & $1.93(1.37-2.15)$ & $1,66(1.39-2.18)$ & $1.87(1.42-2.27)$ & $1.72(1.41-2.16)$ & 0.422 & 1.000 \\
\hline
\end{tabular}

$\mathrm{BNP}=\mathrm{B}$-type natriuretic peptide, $\mathrm{GFR}=$ glomerular fitration rate, $\mathrm{ICU}=$ intensive care unit, $\mathrm{MCS}=$ mechanic circulatory support, $\mathrm{RVAD}=$ right ventricular assist device.

$P$-value was coded: $P<0.05 *, P<0.01 * *, P<0.001 * * *$. 
Table 2. Detailed description of clinical events in clinical groups A and B.

\begin{tabular}{llr}
\hline Group A & Type of complication & $\begin{array}{c}\text { Number of events } \\
(\mathrm{n}=21)\end{array}$ \\
\hline Severe infection & Sepsis & $2(9 \%)$ \\
& Pneumonia & $2(9 \%)$ \\
& Pyothorax & $1(4.5 \%)$ \\
& Mediastinitis & $1(4.5 \%)$ \\
& Clostridium difficile colitis & $1(4.5 \%)$ \\
& Pump pocket infection & $1(4.5 \%)$ \\
& Decubitus infection & $1(4.5 \%)$ \\
Heart failure & Right heart failure requiring hospitalization and parenteral treatment & $3(14 \%)$ \\
& without precipitating event & $2(9 \%)$ \\
& Right heart failure requiring hospitalization due to arrhythmia & $1(4.5 \%)$ \\
Pump thrombosis & Right heart failure requiring hospitalization due to drug non-compliance & $6(29 \%)$ \\
\hline & & Number of events \\
Group B & & $(\mathrm{n}=38)$ \\
\hline Other infections & Acute bronchitis & $8(21 \%)$ \\
& Urinary tract infection & $2(5 \%)$ \\
Decompensated & Drive line infection & $2(5 \%)$ \\
arterial hypertension & & $10(26 \%)$ \\
Heart failure & Right heart failure managed in the out-patient settings & $16(43 \%)$ \\
\hline
\end{tabular}

follow-up of 298 days (159-456) 8 patients (6\%) died, 92 patients $(67 \%)$ underwent heart transplantation and 5 patients $(4 \%)$ were weaned off the LVAD device. The remaining 31 patients $(23 \%)$ continued with LVAD support. Table 2 summarizes adverse events. Group A included 21 patients $(15 \%)$ with severe clinical complications requiring hospitalization, group B comprised 38 patients (28\%) with less severe complications managed in the out-patient setting, group C included 66 patients (49\%) with uneventful clinical course. Group D included the above mentioned 11 individuals (8\%) with uneventful clinical course and decreasing BNP plasma levels which precluded assessment of BNP minimum, BNP peak levels and percent changes. However, Group C and D were analysed together to assess the predictive value of pre-implant variables and data from the first out-patient visit. One-year survival estimates from the Kaplan-Meier analysis were worst in group A (78\%) followed by groups B and C (92\% and 97\%).

\section{Results of BNP monitoring}

At the first out-patient visit, a median time of 64 days (48-88) after implantation, we observed a significant drop in median BNP plasma levels from the pre-implant values: $1894 \mathrm{ng} / \mathrm{L}$ (1255-2917) vs. $342 \mathrm{ng} / \mathrm{L}$ (219-549), $P=0.000$. There was a marked stepwise increase in the median of peak BNP plasma level in group C (BNP peak), and median BNP plasma level in the case of less severe clinical events in group B and severe events in group A: $246 \mathrm{ng} / \mathrm{L}$ vs. 506 $\mathrm{ng} / \mathrm{L}$ vs. $1221 \mathrm{ng} / \mathrm{L}, P=0.000$. As shown in Table 1 , individuals with adverse events (group A and B) had a longer stay in ICU after LVAD implantation, higher BNP plasma levels at the first out-patient visit and at the event (BNP peak) than remaining individuals. There were no differences between groups in their estimated glomerular filtration rate.

\section{Identification of adverse events using BNP monitoring}

Both the absolute value of the BNP peak and percentage values relative to pre-implant, first visit and minimum BNP were able to differentiate individuals with adverse events (group A and B) from group C (Table 3). Only the absolute and percentage values of peak BNP were able to identify individuals with severe adverse events (group A). Interestingly, absolute values of peak BNP and their percentage values had similar areas under the curve (AUC) to identify adverse events. In addition, the AUC of peak BNP rose from identification of infectious complications to diagnosis of heart failure and culminated in individuals with pump thrombosis (Table 3 ). In all the above clinical settings peak BNP plasma levels were significantly elevated over the remaining patients: in infection [617 $\mathrm{ng} / \mathrm{L}$ (414-1135) vs. $422 \mathrm{ng} / \mathrm{L}$ (207-780), $P=0.011]$, in heart failure [737 ng/L (479-1095) vs. $403 \mathrm{ng} / \mathrm{L}$ (191-753), $P=0.000]$ and in the case of pump thrombosis $[1301 \mathrm{ng} / \mathrm{L}$ (1102-1830) vs. $429 \mathrm{ng} / \mathrm{L}$ (220-773), $P=0.000]$.

\section{DISCUSSION}

To the best of our knowledge, this is the first report on serial BNP monitoring in out-patients with a continuousflow LVAD which correlates repeated measurements of BNP with clinical events during follow-up. The main findings can be summarized as follows. First, the latest BNP plasma level differentiated patients with ongoing adverse events from individuals with uneventful clinical course. Second, the efficacy of BNP monitoring to detect adverse event rose from diagnosis of infection to identification of heart failure and culminated in patients with pump thrombosis. Finally, evaluation of absolute values of BNP 
Table 3. Results of receiver operating characteristics analysis with selected cut-off points of variables identifying adverse events.

\begin{tabular}{lllll}
\hline & Variable & $\begin{array}{l}\text { Cut-off points } \\
\text { (sensitivity, specificity) }\end{array}$ & $\begin{array}{l}\text { AUC } \\
(95 \% \text { CI })\end{array}$ & $P$ \\
\hline Differentiation of groups & BNP peak & $\geq 327 \mathrm{ng} / \mathrm{L}(91 \%, 65 \%)$ & $0.863(0.801-0.925)$ & $0.000 * * *$ \\
A+B from group C & BNP peak/BNP pre-implant (\%) & $\geq 18 \%(91 \%, 60 \%)$ & $0.879(0.820-0.938)$ & $0.000 * * *$ \\
& BNP peak/BNP first visit (\%) & $\geq 97 \%(88 \%, 41 \%)$ & $0.758(0.673-0.842)$ & $0.000 * * *$ \\
& BNP peak/BNP minimum (\%) & $\geq 173 \%(93 \%, 76 \%)$ & $0.904(0.851-0.956)$ & $0.000 * * *$ \\
\hline Differentiation of group A & BNP peak & $\geq 609 \mathrm{ng} / \mathrm{L}(90 \%, 78 \%)$ & $0.914(0.853-0.976)$ & $0.000 * * *$ \\
from groups B+C & BNP peak/BNP pre-implant (\%) & $\geq 39 \%(95 \%, 83 \%)$ & $0.938(0.892-0.984)$ & $0.000 * * *$ \\
& BNP peak/BNP first visit (\%) & $\geq 123 \%(86 \%, 75 \%)$ & $0.887(0.807-0.966)$ & $0.000 * * *$ \\
& BNP peak/BNP minimum (\%) & $\geq 206 \%(90 \%, 62 \%)$ & $0.906(0.842-0.969)$ & $0.000 * * *$ \\
\hline Differentiation of group A A & BNP peak & $\geq 781 \mathrm{ng} / \mathrm{L}(81 \%, 68 \%)$ & $0.833(0.721-0.944)$ & $0.000 * * *$ \\
from group B & BNP peak/BNP pre-implant (\%) & $\geq 40 \%(90 \%, 65 \%)$ & $0.864(0.769-0.958)$ & $0.000 * * *$ \\
& BNP peak/BNP first visit (\%) & $\geq 128 \%(86 \%, 65 \%)$ & $0.819(0.705-0.932)$ & $0.000 * * *$ \\
& BNP peak/BNP minimum (\%) & $\geq 297 \%(81 \%, 65 \%)$ & $0.812(0.690-0.944)$ & $0.000 * * *$ \\
\hline Identification of infection & BNP peak & $\geq 414 \mathrm{ng} / \mathrm{L}(76 \%, 50 \%)$ & $0.681(0.569-0.792)$ & $0.009 * *$ \\
$(\mathrm{n}=21)$ & BNP peak/BNP pre-implant (\%) & $\geq 22 \%(71 \%, 48 \%)$ & $0.685(0.565-0.805)$ & $0.008 * *$ \\
& BNP peak/BNP first visit (\%) & & $0.584(0.458-0.710)$ & 0.227 \\
& BNP peak/BNP minimum (\%) & $\geq 183 \%(90 \%, 56 \%)$ & $0.728(0.637-0.819)$ & $0.001 * *$ \\
\hline Identification of heart & BNP peak & $\geq 419 \mathrm{ng} / \mathrm{L}(86 \%, 53 \%)$ & $0.753(0.662-0.844)$ & $0.000 * * *$ \\
failure & BNP peak/BNP pre-implant (\%) & $\geq 23 \%(91 \%, 57 \%)$ & $0.758(0.663-0.853)$ & $0.000 * * *$ \\
$(\mathrm{n}=22)$ & BNP peak/BNP first visit (\%) & $\geq 100 \%(73 \%, 56 \%)$ & $0.707(0.589-0.824)$ & $0.002 * *$ \\
& BNP peak/BNP minimum (\%) & $\geq 208 \%(86 \%, 63 \%)$ & $0.772(0.684-0.860)$ & $0.000 * * *$ \\
\hline Identification of pump & BNP peak & $\geq 783 \mathrm{ng} / \mathrm{L}(100 \%, 77 \%)$ & $0.927(0.859-0.995)$ & $0.000 * * *$ \\
thrombosis & BNP peak/BNP pre-implant (\%) & $\geq 40 \%(100 \%, 75 \%)$ & $0.920(0.853-0.988)$ & $0.001 * *$ \\
$(\mathrm{n}=6)$ & BNP peak/BNP first visit (\%) & $\geq 190 \%(83 \%, 84 \%)$ & $0.835(0.664-0.999)$ & $0.006 * *$ \\
& BNP peak/BNP minimum (\%) & $\geq 550 \%(83 \%, 94 \%)$ & $0.901(0.820-0.998)$ & $0.001 * *$ \\
\hline
\end{tabular}

AUC=area under the curve, $\mathrm{CI}=$ confidence interval

$P$-value was coded: $P<0.05 *, P<0.01 * *, P<0.001 * * *$

at a clinical event appears to have similar value to analysis of intra-individual variation of BNP in these individuals.

\section{Comparison with previous studies}

Although several studies have confirmed LV reverse remodeling and decrease of BNP plasma levels after LVAD implantation ${ }^{13-17}$, there is scarce evidence regarding clinical consequences of BNP monitoring in these individuals $^{18}$. The only comparable study was published by Sato et al. ${ }^{18}$ on a cohort of 83 patients with mainly pulsatile LVADs and 14 deaths (17\%). This paper identified 60-day BNP plasma level as an independent predictor of all cause mortality with a BNP cut-off point of $322 \mathrm{ng} / \mathrm{L}$. Lower mortality in our group ( 8 deaths, 6\%) precluded such analysis. On the other hand, detailed correlation BNP monitoring with adverse events in our study revealed a strong relationship of the latest BNP with ongoing adverse events. Our study thus provided a unique opportunity to define BNP cut-off points to identify individuals suffering from any adverse events ( $327 \mathrm{ng} / \mathrm{L})$, severe adverse events (609 ng/L), infection or heart failure (414-419 ng/L), and most importantly patients with pump thrombosis (783 ng/L). Pump thrombosis may be difficult to diagnose. The current diagnostic schemes include other predictors than BNP such as new-onset heart failure, signs of haemolysis, increased pump power or pathologic result of "ramp" test ${ }^{20-23}$. Marked elevation of BNP could become an additional sign suggesting pump thrombosis.

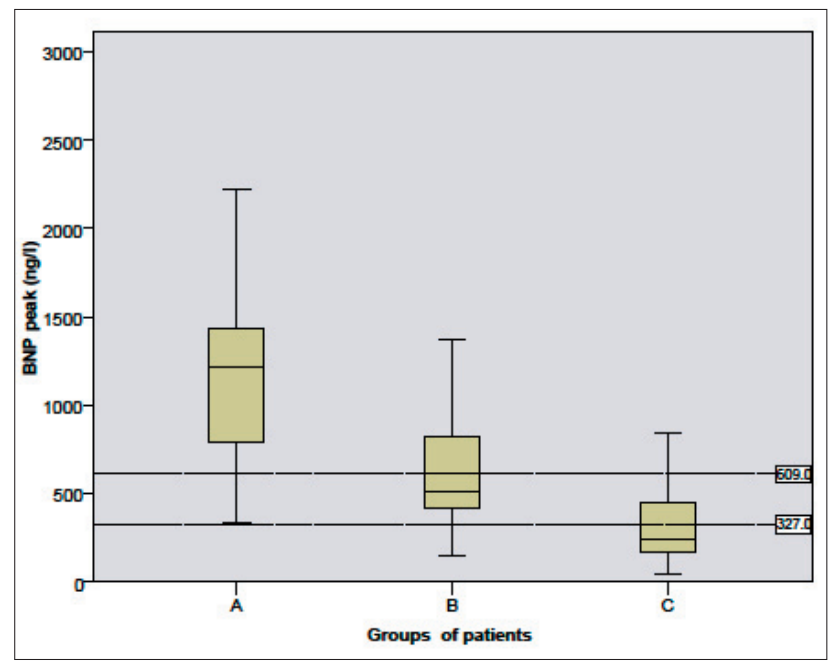

Fig. 1. Comparison of peak B-type natriuretic peptide (BNP) plasma levels in patients with severe adverse events (group A), other adverse events (group B) and uneventful clinical course (group C). Data are shown as a boxplot. Dashed lines indicate optimal cut-off points separating group $\mathrm{A}$ from groups $\mathrm{B}$ and $\mathrm{C}$ (609 ng/L) and groups A + B from group C (327 ng/L). 
Insights into pathophysiology of BNP in LVAD recipients

The main triggers of increased synthesis and release of BNP in LVAD recipients with ongoing adverse events seems to be an increase in left ventricular filling pressures or left ventricular dilatation leading to increased wall stress. These mechanisms are relevant in LVAD patients with decompensated arterial hypertension, which worsens pump flow, and then in decompensated heart failure and pump thrombosis, which leads to severe hemodynamic deterioration. Reasons for BNP elevation in infection are less obvious ${ }^{24-26}$. However, cytokine release and their negative inotropic effect with resulting worsening of contractility and LV filling pressures seem to be a plausible explanation ${ }^{24-26}$. We found no differences in renal function between groups, which suggest that impaired renal degradation is not involved in elevation of BNP plasma levels.

Surprisingly, absolute values of the latest BNP had a similar diagnostic performance as relative values that might reflect intra-individual variability. In theory, assessment of intra-individual variability should be more effective. However, both changes in BNP and percentage values of BNP depend on the absolute baseline plasma levels, which induces noise into the analysis. In agreement with our previous experience with repeated measurement of natriuretic peptides in chronic heart failure ${ }^{8}$, we found that the absolute value of the latest BNP in LVAD recipients has the same diagnostic accuracy as relative values and is more practical.

\section{Study limitations}

This study was not designed to identify predictors of mortality in out-patient LVAD recipients. Although it was prospective, it was not designed to evaluate the independent value of BNP to diagnose specific adverse events in comparison with results of clinical assessment, laboratory analysis and imaging. Finally, the study results, especially identified cut-off points, have to be considered specific for the present subject sample and may vary in different populations.

\section{CONCLUSION}

Serial measurement of BNP in outpatients with LVAD correlates with occurrence of adverse events and may improve their diagnostics. Assessment of absolute values of BNP at the clinical event seems to have a similar accuracy as analysis of intra-individual variation of BNP and it is more practical to use.

\section{ABBREVIATIONS}

AUC, Area under the curve; BNP, B-type natriuretic peptide; CHF, Chronic heart failure; GFR, Glomerular filtration rate; LV, Left ventricular; LVAD, Left ventricle assist device.

Acknowledgement: This study was supported by the research grant of the Ministry of Health, Czech Republic
[MZ 15-27682A], and by the project of the Ministry of Health, Czech Republic for development of research organization 00023001 (IKEM, Prague, Czech Republic). Author contributions: $\mathrm{MH}$ : conceived the idea, literature search, manuscript drafting; $\mathrm{MK}$ : substantial contributions to the concept of manuscript, manuscript drafting, statistical analysis; IN contributions to the concept; VL: statistical analysis; IM: supervised the project. All authors read and approved the final manuscript.

Conflict of interest statement: The authors state that there are no conflicts of interest regarding the publication of this article.

\section{REFERENCES}

1. Kirklin JK, Naftel DC, Pagani FD, Kormos, RL, Stevenson LW, Blume ED, Myers SL, Miller MA, Baldwin JT, Young JB. Seventh INTERMACS annual report: 15,000 patients and counting Seventh INTERMACS. J Heart Lung Transplant 2015;34:1495-1504.

2. Mcllvennan CK, Magid KH, Ambardekar AV, Thompson JS, Matlock $\mathrm{DD}$, Allen LA. Clinical outcomes following continuous-flow left ventricular assist device: a systematic review. Circ Heart Fail 2014;7:100313.

3. Ruskoaho H. Cardiac hormones as diagnostic tools in heart failure. Endocrine Rev 2003; 24(3):341-56.

4. Tsai SH, Lin YY, Chu SJ, Hsu CW, Cheng SM. Interpretation and use of natriuretic peptides in non-congestive heart failure settings. Yonsei Med J 2000;51(2):151-63.

5. Maisel AS, Krishnaswamy P, Nowak R, McCord J, Hollander JE, Duc P, Omland T, Storrow AB, Abraham WT, Wu AHB, Clopton P, Steg PG, Westheim A, Knudsen CW, Perez A, Kazanegra R, Herrmann $\mathrm{HC}, \mathrm{McCullough}$ PA. Rapid measurement of B-type natriuretic peptide in the emergency diagnosis of heart failure. $\mathrm{N}$ Engl J Med 2002;347:161-7.

6. Jannuzzi JL, Van Kimmenade R, Lainchbury J, Bayes-Genis A, Ordonez-Llanos J, Santalo-Bel M, Pinto YM, Richards M. NT-pro BNP testing for diagnosis and short-term prognosis in acute destabilized heart failure: an international pooled analysis of 1256 patients. Eur Heart J 2006;27:330-7.

7. Bettencourt P, Frioes F, Azevedo A, Dias P, Pimenta J, RochaGoncalves F, Ferreira A. Prognostic information provided by serial measurement of brain natriuretic peptide in heart failure. Int J Cardiol 2004;93:45-8.

8. Kubánek M, Goode K, Lánská V, Clark AL, Cleland JGF. The prognostic value of repeated measurement of $\mathrm{N}$-terminal pro-B-type natriuretic peptide in patients with chronic heart failure due to left ventricular systolic dysfunction. Eur J Heart Fail 2009;11:367-77.

9. Kociol RD, Horton JR, Fonarow GC, Reyes EM, Shaw LK, O'Connor CM, Felker GM, Hernandez AF. Admission, discharge, or change in B-type natriuretic peptide and long-term outcomes: data from Organized Program to Initiate Lifesaving Treatment in Hospitalized Patients with Heart Failure (OPTIMIZE-HF) linked to Medicare claims. Circ Heart Fail 2011;4:628-36.

10. Knebel F, Schimke I, Pliet K, Schattke S, Martin S, Borges AC, Baumann G. NT-proBNP in acute heart failure: Correlation with invasively measured hemodynamic parameters during recompensation. J Card Fail 2005;11(5):S38-S41.

11. de Jonge N, van Wichen DF, Schipper ME, Lahpor JR, Gmelig-Meyling FHJ, Robles de Medina EO, de Weger RA. Left ventricular assist device in end-stage heart failure: persistence of structural myocyte damage after unloading. An immunohistochemical analysis of the contractile myofilaments. J Am Coll Cardiol 2002;39:963-9.

12. Frazier $\mathrm{OH}$, Myers TJ. Left ventricular assist system as a bridge to myocardial recovery. Ann Thorac Surg 1999;68:734-41.

13. Sodian R, Loebe M, Schmitt C, Potapov EV, Siniawski H, Müller J, Hausmann H, Zurbruegg HR, Weng Y, Hetzer R. Decreased plasma concentration of brain natriuretic peptide as a potential indicator of cardiac recovery in patients supported by mechanical circulatory assist systems. J Am Coll Cardiol 2001;38:1942-9.

14. Milting $H$, El Banayosy A, Kassner A, Fey O, Sarnowski P, Arusoglu L, 
Thieleczek R, Brinkmann T, Kleesiek K, Körfer R. The time course of natriuretic hormones as plasma markers of myocardial recovery in heart transplant candidates during ventricular assist device support reveals differences among device types. J Heart Lung Transplant 2001;20:949-55.

15. Kemperman $H$, van den Berg $M$, Kirkels $H$, de Jonge N. B-type natriuretic peptide (BNP) and $\mathrm{N}$-terminal proBNP in patients with endstage heart failure supported by a left ventricular assist device. Clin Chem 2004;50:1670-2.

16. Bruggink $A H$, de Jonge $N$, van Oosterhout MFM, Van Wichen DF, de Koning E, Lahpor JR, Kemperman H, Gmelig-Meyling FHJ, de Weger RA. Brain natriuretic peptide is produced both by cardiomyocytes and cells infiltrating the heart in patients with severe heart failure supported by a left ventricular assist device. J Heart Lung Transplant 2006:25:174-80.

17. Wohlschlaeger J, von Winterfeld M, Milting $H$, El Banayosy A, Schmitz KJ, Takeda A, Takeda N, Azhari P, Schmid C, August C, Schmid KW Baba HA. Decreased myocardial chromogranin A expression and colocalization with brain natriuretic peptide during reverse cardiac remodeling after ventricular unloading. J Heart Lung Transplant 2008;27:442-9.

18. Sato $T$, Seguchi O, Iwashima $Y$, Yanase M, Nakajima S, Hieda M, Watanabe T, Sunami H, Murata Y, Hata H, Fujita T, Kobayashi J, Nakatani. Serum brain natriuretic peptide concentration 60 days after surgery as a predictor of long-term prognosis in patients implanted with a left ventricular assist device. ASAIO Journal 2015;61:373-8.

19. Cockroft DW, Gault MH. Prediction of creatinine clearance from serum creatinine. Nephron 1976;16:31-41.

20. Mehra MR, Stewart GC, Uber PA. The vexing problem of throm- bosis in long-term mechanical circulatory support. J Heart Lung Transplant 2014;33:1-11.

21. Goldstein DJ, John R, Salerno C, Silvestry S, Moazami N Horstmanshof D, Adamson R, Boyle A, Zucker M, Rogers J, Russell $\mathrm{S}$, Long J, Pagani F, Jorde U. Algorithm for the diagnosis and management of suspected pump thrombus. J Heart Lung Transplant 2013;32:667-70.

22. Uriel N, Morrison KA, Garan AG, Kato TS, Yuzefpolskaya M, Latif $F_{\text {, }}$ Restaino SW, Mancini DM, Flannery M, Takayama H, John R, Colombo PC, Naka Y, Jorde UP. Development of a novel echocardiography ramp test for speed optimization and diagnosis of device thrombosis in continuous-flow left ventricular assist devices. J Am Coll Cardiol 2012;60:1764-75.

23. Uriel N, Han J, Morrison KA, Nahumi N, Yuzefpolskaya M, Garan AR, Duong J, Colombo PC, Takayama, H, Thomas S, Naka Y, Jorde UP. Device thrombosis in Heart Mate II continuous-flow left ventricular assist devices: A multifactorial phenomenon. J Heart Lung Transplant 2014;33:51-9.

24. Habib FM, Springal DR, Davies DJ, Oakley CM, Polak J M, Yacoub MH Tumor necrosis factor and inducible nitric oxide synthase in dilated cardiomyopathy. Lancet 1996;347:1151-5.

25. Holman WL, Kirklin JK, Naftel DC, Kormos RL, Desvign-Nickens $P$, Camacho MT, Ascheim DD. Infection after implantation of pulsatile mechanical circulatory support device. J Thorac Cardiovasc Surg 2010;139:1632-6.

26. Milting $\mathrm{H}$, Ellinghaus $P$, Seewald $M$, Cakar $H$, Bohms B, Kassner $A$, Körfer R, Klein M, Krahn T, Kruska L, I Banayosy AE, Kramer F. Plasma biomarkers of myocardial fibrosis and remodeling in terminal heart failure patients supported by mechanical circulatory support devices. J Heart Lung Transplant 2008:27:589-96. 